\title{
Critiquing Child characters as Heroes, Villains, and Victims in Ru Freeman's On Sal Mal Lane
}

\author{
Sneha Choudhary ${ }^{1}$, Priyanka Chaudhary ${ }^{2}$ \\ ${ }^{1}$ Department of Languages, Manipal University Jaipur, Rajasthan, India \\ csneha46@gmail.com \\ ${ }^{2}$ Professor, Department of Languages, Manipal University Jaipur, Rajasthan, India. \\ priyanka.chaudhary@jaipur.manipal.edu
}

\begin{abstract}
Social behaviour and filial background define the formation and development of a character that is bound by cultural influence in South Asian fiction. Ru Freeman weaves numerous characters and their stories in a single lane as a synecdoche of Sri Lankan history. On Sal Mal Lane (2014) showcases the different social groups defining the Sri Lankan conflict in the 1980s with the presence of child characters who are unaware of the extent of the ethnic conflict swirling in the background of the narrative. This paper tries to define the concepts of heroes, villains, and victims through the socio-emotional development of the characters to determine the contradiction between their intentions and subsequent actions. The study uses Character Theory and elements of Affect Control Theory for critical analysis. The paper analyses the change in personality traits of child characters in response to the violence wrought by Sri Lankan ethnic prejudices and the extent of destructive development from the unstable familial and societal environment.
\end{abstract}

Keywords: Character Theory, On Sal Mal Lane, Socio-emotional Development, Sri Lankan ethnic war, Affect Control Theory, Child characters

\section{Introduction}

Structuralist Narratology has long since exhausted the concept of 'Character' in analysing one of the major elements of fiction. Aristotle defines 'Character' as the catalyst of advancing the plot forward and unifying the plot with its participation. Even the abridged version of Aristotle's study of poetry and consequently drama defines the elements of a fictional account by centralising the importance of plot rather than character.

"Aristotle and the Formalists, and some structuralists subordinate character to plot, make it a function of plot, a necessary but derivative consequence of the chrono-logic of story" (Chatman, 1980, p.113). Seymour Chatman (1980) in his book Story and Discourse: Narrative Structure in Fiction and Film discusses the concept of 'Character' in detail by analysing its journey historically through numerous structuralists' theoretical analysis. The history of 'Character Analysis' shows the subordinate nature of 'Character' as an element of the narrative. It is merely a tool to use for the plot to unfold. But many character analysts like Seymour Chatman, James Phelan, and Vladimir Propp have defined 'Character' depending on the emerging diverse nature of character formation in literary works.

(C) AesthetixMS 2021. This Open Access article is published under a Creative Commons Attribution Non-Commercial 4.0 International License (http://creativecommons.org/licenses/by-nc/4.o/), which permits non-commercial re-use, distribution, and reproduction in any medium, provided the original work is properly cited. For citation use the DOI. For commercial re-use, please contact editor@rupkatha.com. 
Even though French narratologists have also dictated Aristotle and Formalists' definition of character being 'means rather than end of the story' (Chatman, 1980) which is contradictory to Vladimir Propp's Character Theory borne out of his analysis of fairy tales and organised to "demonstrate the psychological or moral evaluation of character" (Propp, 1928, as cited in Chatman, 1980). Propp classifies characters into the roles of 'Hero', 'Villain', 'Victim', and so forth which coincides with Shakespearean use of characterization and plot as well. The characters in Shakespeare's plays often have distinct features defining the overall plot. The categorisation of 'Hero' and 'Villain' is distinctly visible through the tragedies and comedies of the Elizabethan age which brought forth the importance of character as a unifying factor of the whole plot.

One of the major observations reveals that the characters of a novel are more comprehensible in their journey of cognitive narrative and development through the novel (Weststeijn, 2004). The narrative in a novel allows a layered representation of its characters which gives much space for analysis. Character Theory as an extension of Narrative Theory focuses on characters' role in moving the plot by defining the categories of good and evil (Bergstrand \& Jasper, 2018). Traditionally, these categories were definitive in their divisions of moral consciousness because the character brought moral imperative into a narrative due to the extent to which the literary rhetoric plays with the 'Character'. Since then, complexity and depth of character have increased as visible through contemporary writers who are able to highlight the contradictory layers of a particular personality formation. These layers of personality are termed as the 'paradigm of traits' by Seymour Chatman in his criticism of character analysis (Chatman, 1980; Bergstrand \& Jasper, 2018). The moral imperative is shown through these complex traits of characters. Similarly, child characters have traditionally been associated with purity and innocence which creates a pedestal of morality in any social structure contradicting the corrupt and violent elements.

The socio-emotional development of child characters as represented in literary works needs a functioning social setting that ultimately creates social relationships formed through interactions. These interactions are guided by affective meanings. Social behaviour can also be explained through the Affect control theory as postulated by David Heise (1977,1970, as cited in Robinson et al., 2006).

David Heise is attributed for bringing much change in the sociology of emotions by his theory which used behaviour in the social context to find affective meanings (1977,1979 as cited in Robinson et al.,2006). It is a kind of interactionism that presents social actors whose goal is to find affective meanings which are attributed to different symbols of a social setting. The social identities and actions carried by the social actors often define the affective meaning of that specific cultural background (Robinson et al., 2006). Ethnic identity has been a major catalyst of divisiveness in many South Asian societies. One of which is the civil war of Sri Lanka due to the unrest between the Sinhala and Tamil communities.

Sri Lanka observed healthy political transference from its colonizers when it gained independence in 1948. The diverse ethnicities came together to fight against a common fight which indicated a non-violent succession of power. It also put Sri Lanka in an advantageous position compared to its other South Asian counterparts. This was predicted to be beneficial, but ethnic segregation became the cause of social and political unrest. This unrest became violent which resulted in a long civil war that began in 1983 and ended in 2009 when Sri Lankan armed forces defeated Liberation Tigers of Tamil Eelam (LTTE). The Sinhalese and Tamil communities have been at odds due to deliberate divisive notions planted before independence which grew through political interference in deliberate suppression of the Tamil community in political and economic arenas (Adriana, 2014; Ganguly, 2018). 
$\mathrm{Ru}$ Freeman has created a synecdoche of Sri Lanka in a single lane in her novel. The representation of different ethnic identities, which have long since defined Sri Lanka and its civil war, gave ample opportunities for Freeman to showcase the emerging prejudices and ethnic segregation through various ethnically diverse families of the lane. The reader is able to divide the numerous politically and divisive notions expressed through the characters and consequently adopted by the children. Freeman has given abundant space to child characters as they become a catalyst for change and constructive criticism of the adult world.

“... moments to which writers go back over and over again because they signify the reasons for the start of the ethnic conflict, a rending of one type of nationalism and the inauguration of another" (Jayasuriya,2016, p.196). It is specifically visible through the narratives of Nayomi Munaweera, Shyam Selvadurai, and Michael Ondaatje. Many novelists chose to showcase the destructive impact of the Sri Lankan civil war through child characters and the trauma and displacement they experienced at the advent of ethnic discrimination. Shyam Selvadurai's Funny Boy (1994) is representative of the loss of innocence through the protagonist, Arjie, by the end of the narrative due to the loss of their native home of Sri Lanka (Pradhan, 2019, p.200). "Nayomi Munaweera's debut novel explicates the history of the emergence of liberation Tigers of Tamil Ealam and clamour for a separate homeland by Tamils inhabited in Sri Lanka" (James, 2019, p.49). Sri Lankan literature in English is heavily dominated by the ethnic war which has naturally become the psyche of a whole generation who has lived through the violence and trauma. Similarly, Freeman uses political discourse to showcase the different policies which intensified the angst of the Tamil population towards the Sri Lankan government and led to the formation of LTTE (Jayasuria,2016). She further establishes Sal Mal Lane as a singular entity as compared to the nation collectively. There is a healthy division of ethnic identities amidst the families living on the lane and subsequently, the child characters are also representative of their family's collective political views. The children create an alternative space where the ethnically diverse communities could live in harmony as they are not prone to discrimination unless their primary caretaker creates a prejudicial schematic formation in their psyche.

"Heise hoped to develop a formal framework that could describe both the routine, expected role behaviors that people enact under normal circumstances and the creative responses they generate when encountering noninstitutionalised or counter-normative situations" (Robinson et al., 2006, p.179). These counter normative situations are not rare, and a developing child's cognitive analysis could take them in any direction of thought and action. Ru Freeman (2014) uses these types of situations to present the emotional response of children in her novel On Sal Mal Lane. These situations could bring a major change in the personalities of cognitive and emotional development of children. They often project the formation of personality traits influenced by their environment or familial spaces (Bandura, 1989). The selective analysis of the developing years of child characters can show the birth of prejudices and discriminatory mindset amidst the flood of diverse ethnic identities in Sri Lanka (Saltarelli \& Bush, 2000). The paper will categorize the normative notion of good and evil by defining the actions of characters and the emotions behind their motive.

\section{Discussion and Analysis}

\section{Depiction of Child Characters in On Sal Mal Lane}

On Sal Mal Lane starts with a single event that brings numerous changes and attributes distinct affective meanings to otherwise unnoticeable social elements. The advent of the Herath family on the Sal Mal Lane changes the dynamics of the social scene and represents an inclusive social group that is unbothered by distinct ethnic identities and believes in a 
harmonious society. This harmony is symbolized through the singing of Herath children which is the first event that forms contrasting impressions in the minds of other residents of the lane. They expressed distinct 'affective meanings' to their 'impressions' (Robinson et al., 2006) which showcases their attitudes and beliefs on multiple issues. These impressions are mainly accorded with the unstable political situation which is significant for the adult social relationships and secondly, the advent of a new set of children also posits change due to their possible influence on the children of the lane.

$\mathrm{Ru}$ Freeman created every child's character by defining their often-contrasting way of behaviour. This started with the Herath children who became an archetype of wellbehaved and model children. The Bollings are in complete contrast with the Herath children which are in part attributed to their familial upbringing where they are not socially disciplined. The Bollings' disregard for a socially acceptable attire differentiates them through unconventional picture in an otherwise social structure. It reflects in the Bolling twin sisters' appearance which changes as they attune themselves with the company of Herath children. Whereas the Silvas tend to teach their children too much regarding the social setting of the lane; their stature remains higher in their minds even within the circle of children who are prejudicial by nature. These descriptions of residents create a synecdoche of varied notions of lifestyle as well as attitude including the representations of every section of Sri Lankan societies.

Freeman has distinguished these three households to also show their distinct perceptions regarding their social identities which were on the brink of causing a civil war in Sri Lanka from 1979 to 1983 . These years are central in changing the political history of Sri Lanka and the clear division is visible with time. The political view of a family usually presents the view of adults which the children mimic or are conditioned to follow. The developing years of the children and their social experiences influence them greatly which also shows contrasting views of their familial social setting (Hurlock, 2018). This feature constantly plays in On Sal Mal Lane as the child characters are often described through multiple levels of their behaviour with or without their primary caretakers.

The advent of the Herath family in Sal Mal Lane brings much excitement, especially amongst children who are apprehensive of the four Herath children. Freeman depicts these siblings as a unit who are not always far behind one another. Their characterization is uniquely defined by their sibling bond with each other which intertwines their thought and action (Stormshak et al., 2009). The older ones, Suren, and Rashmi portray fine examples for their younger siblings, Nihil and Devi, to follow. Devi, being the youngest, is portrayed as the most active and lively character who often gets punished for her mischiefs. Their developing years define their companionship and guidance from each other which is crucial in their social and emotional development (Stormshak et al., 2009). The novel follows their changing outlook towards their parents and consequent support towards each other. Suren and Rashmi bear the burden of being the older siblings which include their increased responsibility towards fulfilling the expectations of their parents while also caring for their younger siblings. Their gentle handling of their siblings often strengthens their bonds as a unit against the adults. 
5 | Critiquing Child characters as Heroes, Villains, and Victims in Ru Freeman's On Sal Mal Lane

\section{Conventional Heroes of On Sal Mal Lane}

The narrative of On Sal Mal Lane is carried forward by the child characters whose life and perceptions dominate the changing social and cultural 'transient meanings'. Their development presents a distinct 'paradigm of traits' (Chatman, 1980) which are prone to change with social events central in Freeman's narrative.

'Hero' in a narrative is representative of all that is good and moral, while the focus is the protection of the vulnerable. The sacrifice to protect the weaker and innocent characters is the drive that guides them (Bergstrand \& Jasper, 2018) and Freeman has specifically denoted these traits while narrating the Herath children.

Nihil, being older than the youngest Devi, is extremely close with her as he feels immensely protective towards her. His fear for Devi is borne out of the superstitious prediction, connected with her birth date, which looms as a dreadful premonition. This superstition dominates Nihil's thoughts due to various social affective meanings of danger attributed to Devi's birthday which becomes a permanent schema in Nihil's psyche. Even with Suren and Rashmi as older siblings, he feels greater responsibility towards Devi. It is imperative to note that sibling relationships play an important part in a child's development and subsequent emotional regulation (Stormshak et al., 2009). This inter-dependency of guidance and emotional comfort is used by Freeman to create a symbiotic relationship between Herath children.

One of the pivotal moments of Nihil's sacrifice comes when he decides to sacrifice his favourite game, cricket, to accompany Devi for her piano lessons with Kala Niles who seemed like a threat at the time: "Someone had to protect Devi from the ogre who took such pleasure in reminding them of his sister's cursed birth date, and he trusted himself alone to do that work" (Freeman, 2014, p.65). The reminder of Devi's birth only strengthened his resolve to protect her at every turn of her life which even crept up in his dreams: "Nihil had only responsibility and fear, which made his nights fretful and his dreams unerringly morbid.” (Freeman, 2014, p.69)

This tendency to always on the lookout for Devi's safety elevates Nihil's sense of responsibility especially when Devi is carefree and often prone to injuries which further increases all her siblings' worries. His evaluation of good versus bad (Osgood, 1962, as cited in Robinson et al., 2006) plays throughout the novel which becomes integral in evaluating Devi's well-being. Nihil's understanding of the mental and emotional states of Devi often guides him in 'knowing' things regarding her which represents the extent of worries his mind is filled with. This quality can be attributed to a character placed in a 'Hero' category as postulated in the Character Theory. But affective social meanings place his potency to be low compared to an adult who could do something regarding the safety of other children. Being a child himself, he was prone to childish activities.

"It would have helped Nihil greatly to know that he was mistaken in this belief, that the same fears rested equally within the minds of his older siblings..." (Freeman,2014, p.68). Suren and Rashmi were, in their limited capacity, guardians of their younger siblings. Freeman attributed responsibility akin to an adult to Suren and Rashmi in taking care of their younger siblings. It is in contrast to the way Sonna and Mohan treat their siblings which is authoritative and cruel. The older Herath children create an invisible safety for the younger ones. There is a constant threat in their psyche due to premonition regarding Devi's death which looms large in Nihil's thoughts. Freeman portrays his individual development as secondary which may have elevated his sense of responsibility and sacrifice but demoted his sense of self and individuality. This defined his position as the 'Hero' as a dependency of his emotional development laid heavily on Devi's safety. 


\section{In growing 'Villain' characteristics during Social Development}

"Villains focus blame, provide a clear target for action, intensify negative emotions, and solidify group identities" (Bergstrand \& Jasper, 2018, p.229). Propp's 'Villain' is filled with negativity and violent manipulations which deepen the intricacies of a narrative. A novel allows the complexity of villainous characters to present the origin of such negative forces in their psyche. This could be further illustrated through contemporary fiction which uses Historical realism as part of the narrative and consequently increases the relative depth of the character. Freeman creates a sense of divisive notions amidst certain characters who are prone to express negative emotions and consequently act through them. These certain characteristics when observed in children bears the question of their socioemotional state. Sonna Bolling is described as a 'bad boy' by his neighbours. He is portrayed as the quintessential 'Villain', but his intentions and subsequent actions are not always reflective of this image.

His delinquencies and crass nature have always dominated his personality traits but the advent of the Herath family posed a test for Sonna to create an image opposite to the usual preconceptions regarding him. As George Mead (1938, as cited in Robinson et al., 2006) defines Affect Control Theory through the intentions of people who maintain a certain balance in their actions to give specific meanings to their social interactions. Sonna's intention reflected his desire to break through his disconnection from society even though his actions do not always resonate the same. To resolve the conflict in his mind and prove his true 'self which was extremely different from the very start, he sought friendships from the Herath children. This proved difficult because his positive actions were always ignored or overlooked but his violent retaliation remained memorable for the other characters.

Every aspect of a child's personality formation is guided by their primary caretakers (Benoit, 2004). Sonna as a child of nine years old was subjected to physical and emotional abuse from his father, Jimmy Bolling. The Bollings as parents did not treat Sonna kindly in his childhood which accumulated into anger and dissatisfaction. Social expectations as part of Social Development becomes secondary when the developing age of a child is overflowed with physical abuse converting Sonna's young mind into a corrupted violent one. He is extremely insecure due to 'atypical' behaviour by his caregivers who are themselves ridden with unresolved disappointments of their life (Benoit, 2004). The feeling of belongingness is also missing in Sonna's case which is important for interdependency with social relationships defining one's individual identity (Dan, 2014; Hurlock, 2018).

His father's physical abuse and consequent negative feelings towards Raju unwittingly make him one of the causes of Devi's death which solidifies his role as the 'Villain'. This categorisation is questionable due to Freeman's presentation of individual cognitive narratives in the novel. Sonna's narrative shows his vulnerability and explains his expression of violence which becomes the only way he could feel powerful. His psychological and emotional regulation is marred with anger and violence which reflects in his antisocial behaviour (Hurlock, 2018).

The Silva family represents the largely prejudiced section of Sri Lankan history that sought to discriminate against the Tamil community. Freeman showcases the Silva family as a unifying prejudiced part of the Sal Mal Lane. Their family discussions exhibit an extreme sense of discrimination against people who are of different communities which in turn influences their older child, Mohan. Being a teenager, Mohan is more prone to act violently towards those social symbols whose affective meanings are labelled with prejudices in his psyche. This behaviour is also borne out of fulfilling his father's expectations and in accordance with his political views. His parents' 
enabling towards such discrimination empowers him in carrying out the level of prejudiced actions which is more than a child could be expected to commit. His parents' support also prevents the label of miscreant on his name even though his negative intentions and subsequent actions towards other people coincide with Sonna's antisocial behaviour. His disposition is of an arrogant rebel in comparison to Sonna's vulnerability in his violence.

Sonna and Mohan are unable to understand the contradiction of Raju's personality which creates an affective notion of hatred in their mind. By terrorising Raju, Sonna and Mohan gain selfworth which is otherwise not possible due to their limited potency in social events. Raju becomes a victim due to the atrocities he is forced to endure. Initially, he is tormented by Sonna which goes on to show his vulnerability in front of a rebellious and misunderstood teenager, but eventually, Devi becomes a catalyst of further terror experienced by Raju. This positions Mohan and Sonna as the tormentors which solidify their role in creating dissension of social harmony on the lane.

Their animosity particularly towards Herath children and Raju is borne out of the overly displayed innocence and positive traits as opposed to unruly terror imposed by Mohan and Sonna. The similarities between them eventually bring them together in their part as the 'Villains' of Sal Mal Lane but differences bring out their distinct mental states and core of their psyche. Mohan is inherently negative towards people who do not align with his constricted worldview, but Sonna is borne through the whips and lashes of his father whose emotional abuse disrupts his psychical development which represses his true 'self' and creates a personality abhorred by social perceptions.

\section{Journey from Innocence to 'Victim'}

Freeman categorises innocence with the sketches of Devi and Raju who reflect Propp's 'Victim' by presenting moral responsibility and innocent vulnerability (Chatman,1980; Bergstrand \& Jasper, 2018). Devi, being the youngest, "embodies the innocence of people in Sri Lanka before the rise of ethnic tensions" (Assella, 2017, p.23). Devi's socioemotional space is extremely influenced by her siblings' guidance in every adventure. Her siblings are extremely protective of her vulnerability as the youngest one and her friendship with Raju is reflective of their shared innocence which is unblemished due to their limited understanding of the world. Devi categorises Raju as her friend without any judgement and her mind attributes the 'affective meaning' (Robinson et al., 2006) of guardian to Raju. Both could be denoted with similar characterizations because of their childlike disposition which labels them in a single group representative of innocence. These traits are often representative of conventional victims who are good and powerless (Bergstrand \& Jasper,2018).

Shashikala Assella (2017) in her study analyses the child characters and other subaltern characters of On Sal Mal Lane to re-write the historical elements from the perspective of the neglected 'Other'. It discusses the various characters through their ethnic and gendered identities and analyses their subaltern narrative. The study further analyses agency of seemingly powerless characters and gives voice to ethnically discriminated and female figures of the novel which also includes the potency of Devi as a character attributing significance to Raju as her chosen guardian.

The innocence of Raju and Devi is repeatedly and symbolically threatened due to the increasing violent sentiments associated with the rising ethnic turmoil. This is also because of Raju's uncommon traits which question his credibility and potency as an adult by making him a target of antisocial elements dominating the Sri Lankan society at the time. Even Dolly and Rose are 'victims' because of their coercive and toxic relationship (Stormshak et al., 2009) with Sonna as the older sibling.

Propp's characterisation puts Devi in the category of 'Victim' as their innocence is bound to get corrupted disrupting the moral compass in the novel. This is further shown through Devi's 
death which is one of the major events in the novel affecting the dynamic of every character. The most beloved child of the Herath family whose protection proved to be fruitless when innocent carelessness by Raju causes her death. The emotional regulation of various characters is disrupted through this incident. Sonna as a 'Villain' is solidified through his part in Devi's accident which could have been prevented but his primary schema is overflowed with his father's physical abuse making him the catalyst to Devi's death. This is reflected through his behaviour towards Raju as well due to his unconscious desire to make Raju the villain despite Raju's character as a caretaker and friend of the children.

This transference of blame from Sonna to Raju in the narrative impacts Nihil extremely because it caused his sister's death. His sacrifices and worries due to Devi's safety which had begun to subside were rendered useless in front of his own eyes. His role as the protector ultimately proves to be powerless in keeping Devi safe. Being a child and losing a sibling changes the affective notions' (Robinson et al.,2006) previously instilled during social development. Nihil faces a similar dilemma that threatens to change his core personality traits. This tragedy changes the heroic symbols of his personality into a 'victim' as emotional processes changes with shifting cognitive and affective structures in his psyche: "...for what they found was not only a child who was gone but a child who was half-gone, and that half-goneness that Nihil embodied gave them something to focus on." (Freeman, 2014, p.343)

The sociocultural 'transient meanings' (Robinson et al., 20o6) regarding ethnic discrimination threatens Nihil's psyche towards adopting traits attributed to hatred due to Devi's death. This presented one of the reasons for the increasingly divisive notion existing in the social structure as the children riddled with tragedies label these social identities with hatred and prejudice. The Herath family has always been inclusive of all social communities and consequently their children as well learn to support communal harmony. This traumatising event during Nihil's development overshadows his family's teachings and generalises an ethnic identity with a single unintended action.

Similarly, the destructive psychological formation of Sonna, due to his father's constant physical abuse, created circumstances marred by the violence of ethnic riots and consequently Raju's unstable disposition resulting in Devi's death. The contradiction of intention and action in this tragedy applies to Sonna as well who accepts his punishment from Raju. It is notable that even with villainous characteristics, Sonna is very much a victim who is helpless in his state of constantly absorbing the psychologically destructive hatred from his caretakers which ultimately results in his death as well. The death of innocence in the novel overshadows Sonna's traumatic life which remains void of kindness.

\section{Conclusion}

$\mathrm{Ru}$ Freeman showcases the change in affective meanings of conventional social structures influenced at national, societal, and familial levels through the narrative of On Sal Mal Lane. This change in meaning influences culturally shared symbols associated with social identities. On Sal Mal Lane presents the change from inclusive ethnic practices towards ethnically profiled violence. The previous state of communal harmony changes due to the creation of opposite affective notions and changes in symbolic meanings of community. This change is illustrated through the child characters whose changing personality traits associated with social development are also the result of the influence of the changing social structure surrounding them. The social interactions of child characters primarily influenced through their caretakers i.e., parents also become one of the major psychical schematic formations. 
The paper categorises distinct 'paradigm of traits' (Chatman, 1950) of characters in On Sal Mal Lane which represent socially and morally conscious agents. The narrative shows that a change in affective meanings changes the perspectives of child characters during their developing years. They face the counter-normative situations of social and political instability resulting in the transference of traits from 'heroic to victim' or 'victim to villain'. Their socioemotional development also defines personality traits that become extremely destructive and violent when faced with physical abuse from primary caretakers. The paper highlights the importance of family in emphasising the constructive formation of a healthy schematic formation of a character's psyche. It is imperative to note that the destructive nature of a child character's development results in 'villainous' personality traits borne out of experiences from being a victim of trauma. It may also be a result of tragic loss of a sibling who dominated a child's emotional regulation destroying their codependent development with their sibling. These counter-normative experiences result in the formation of a 'victimised' personality making them vulnerable towards transferring the blame to a particular social group creating prejudice against them. The normative categories of good and evil dissolve into a combination of contradictory affective meanings of their social interactionism when destructive psychical development becomes a catalyst to destructive social relationships.

A political instability such as the Sri Lankan ethnic war has the tendency to become a catalyst in changing the trajectory of the generation facing trauma and violence. The realistic war narratives combined with bildungsroman fiction exhibit the changing psyche of a developing generation. The research in analysing the disruption of child development could be representative of other fictional narratives of similar settings and decreasing the research gap by increasing the social consciousness in protecting the powerless spectators of the violence.

\section{References}

Adriana, V.M. (2014). The Sri Lankan Civil War: From Conflict to Peace Building. Global Journal of HumanSocial Science: F Political Science, 14(2), 33-41. https://globaljournals.org/item/3289-the-sri-lankan-civilwar-from-conflict-to-peacebuilding .

Assella, S. (2017). Children, Burghers and Tamils On Sal Mal Lane: The Subaltern's Narrative of the Ethnic Riots. Critical and Creative Wings, 4(1), 18-27.

https://www.academia.edu/7423288/Children_Burghers_and_Tamils_On_Sal_Mal_Lane_the_subaltern _s_narrative_of_the_ethnic_riots

Benoit, D. (2004). Infant-parent attachment: Definition, types, antecedents, measurement and outcome. Paediatrics and Child Health, 9(8), 541-545.https://academic.oup.com/pch/articleabstract/9/8/541/2648563

Bergstrand, K. \& Jasper, J.M. (2018). Villains, Victims, and Heroes in Character Theory and Affect Control Theory. Social Psychology Quarterly, 81(3), 228-247. https://doi.org/10.1177/0190272518781050

Chatman, S. (1980). Story and Discourse: Narrative Structure in Fiction and Film. Cornell University Press.

Dan, M. (2014). Early Childhood Identity: Ethnicity and Acculturation. Journal of Education Culture and Society, (1), 145-157. https://www.researchgate.net/publication/306110748_Early_childhood_identity_ethnicity_and_accultur ation .

Fink, G. \& Yolles, M. (2014). The Affective Agency: An Agency with Feelings and Emotions. SSRN Electronic Journal. https://papers.ssrn.com/sol3/papers.cfm?abstract_id=2463283.

Freeman, R. (2014). On Sal Mal Lane. Penguin India. 
Ganguly, S. (2018). Ending the Sri Lankan Civil War. Daedalus, 147(1), 78-89. https://www.mitpressjournals.org/doi/full/10.1162/DAED_a_oo475.

Hurlock, E. (2018). Child Development (6 ${ }^{\text {th }}$ ed.). McGraw Hill Education.

James, J. (2019). Voices of the Trauma: A Dissection of Island of a Thousand Mirrors by Nayomi Munaweera. International Education \& Research Journal,5(3),49-50. http://ierj.in/journal/index.php/ierj/article/view/1848/1756

Jayasuria, M. (2016). Terror, Trauma, Transitions: Representing Violence in Sri Lankan Literature. Indialogs: Spanish Journal of India Studies, 3, 195-209. http://dx.doi.org/10.5565/rev/indialogs.48 .

McHale, S. M., Updegraff, K. A., \& Whiteman, S. D. (2012). Sibling Relationships and Influences in Childhood and Adolescence. Journal of marriage and the family, 74(5), 913-930. https://doi.org/10.1111/j.1741-3737.2012.01011.x

Pradhan, A. (2019). Multiply Exiled: Nostalgia, Re-collection and Re-presentation of the Queer Diaspora in Shyam Selvadurai's Funny Boy. Middle Flight,8(1),193-203. https://www.academia.edu/22573911/Multiply_Exiled_Nostalgia_Re_collection_and_Re_presentation_o f_the_Queer_Diaspora_in_Shyam_Selvadurai_s_Funny_Boy_

Robinson, D. T., Smith-Lovin, L. \& Wisecup, A. K. (2006). Affect Control Theory. In Peter J. Burke (ed.), Contemporary Social Psychological Theories (pp.137-164). Stanford University Press. https://doi.org/10.1007/978-0-387-30715-2_9

Saltarelli, D. \& Bush, K. D. (2000). The Two Faces of Education in Ethnic Conflict: Towards a peacebuilding education for children, Innocent Insights no.4, p.2. https://www.unicef-irc.org/publications/269-thetwo-faces-of-education-in-ethnic-conflict-towards-a-peacebuilding-education-for.html.

Saunders, H., Kraus, A., \& Barone, L., Biringer, Z. (2015). Emotional Availability: theory, research, and intervention. Frontiers in Psychology, 6(1069). https://doi.org/10.3389/fpsyg.2015.01069

Schneider, R. (2001). Toward a Cognitive Theory of Literary Character: The Dynamics of Mental-Model Construction. Style, 35(4), 607-639. https://www.jstor.org/stable/10.5325/style.35.4.607 .

Stormshak, E. A., Bullock, B. M., \& Falkenstein, C. A. (2009). Harnessing the power of sibling relationships as a tool for optimizing social-emotional development. New directions for child and adolescent development, 2009(126), 61-77. https://doi.org/10.1002/cd.257

Thompson, R. A., \& Virmani, E. A. (2012). Socioemotional development. In V. S. Ramachandran (Ed.), Encyclopedia of human behavior (2nd Ed.) (pp. 504-511). Oxford, UK: Elsevier. https://doi.org/10.1016/B978-0-12-37500o-6.00339-6 .

Weststeijn, W. G. (2004). Towards a Cognitive Theory of Character. In L. Fleishman, C. Goelz \& A.A.H. Lion (eds.), Analyzing as interpreting: Wolf Schmid on his $60^{\text {th }}$ birthday (pp.53-65). Hamburg University Press. https://d-nb.info/1058341693/34

Sneha Choudhary is a Research Scholar of English in the Department of Languages, School of Humanities \& Social Sciences at Manipal University Jaipur, India. Her research area is based on Child Development in South Asian literature.

Priyanka Chaudhary is a Professor of English and Head of Department of Languages, School of Humanities \& Social Sciences at Manipal University Jaipur, India. Having sixteen years of teaching UG and PG students, she has also supervised five doctoral research scholars and four scholars are currently pursuing their PhDs under her supervision. Her interest lies in South Asian Cultural Studies. She has published four books and numerous research papers. 